\title{
Attendees Preference Modelling for an International Art Festival Based on Show Attendances
}

\author{
Stephen Boyle ${ }^{1}$, Carmen Joham ${ }^{2} \&$ ABM Abdullah ${ }^{1}$ \\ ${ }^{1}$ School of Management, UniSA College, University of South Australia, Australia \\ ${ }^{2}$ School of Management, University of South Australia, Australia \\ Correspondence: Stephen Boyle, UniSA College, University of South Australia, Adelaide SA 5000, Australia. \\ Tel: 61-8-8302-7857. E-mail: stephen.boyle@unisa.edu.au
}

$\begin{array}{ll}\text { Received: February 15, } 2012 & \text { Accepted: April 12, } 2012 \quad \text { Published: June 1, } 2012 \\ \text { doi:10.5539/ijbm.v7n11p18 } & \text { URL: http://dx.doi.org/10.5539/ijbm.v7n11p18 }\end{array}$

\begin{abstract}
Falassi (1997) regards festivals as a time of celebration. Can festivalsbe considered catalysts for experiencing local art and culture or do they serve to promote an internationalised version of culture? This paper explores the role of arts festivals on local cultural consumption through festival attendees' preferences to particular styles of cultural performances. Using data from the 2009 Hong Kong Arts Festival the paper seeks to identify the factors underlining attendee preferences. Findings show that there is a demand for a balance of local and international cultural experiences. This result highlights the dual role of major festivals of both bringing the best of international art to local residents while also showcasing the traditional and contemporary culture of the region.
\end{abstract}

Keywords: arts festivals, cultural consumption, cultural attractions, Asian market, Hong Kong

\section{Introduction}

Festivals are a growing phenomenon in modern economies (Prentice \& Andersen, 2003). This 'festivalisation' of culture has seen as an explosion of artistic, cultural and other popular activitiescondensed into short periods of concentrated effort for maximum impact. In fact as noted by Fjell (2007) festivals in Europe have increased in the last 60 years from around 400 to over 30,000 annually. As such they are significant contributors to the cultural life of many cities (Arcodia\&Whitford, 2006) and therefore are of interest to arts managers and policy developers alike.

It has been noted that cultural festivals are now a significant mainstay on the cultural calendar of modern society (Crespi-Vallbona\& Richards, 2007). Crespi-Vallbona and Richards (2007) go on to state that festivals take on a variety of roles extending from mechanisms to sustain cultural groups, to mechanisms for assuring the acceptance of a particular cultural discourse to a means of generating local pride, identity and income (Crespi-Vallbona\& Richards, 2007). However they suggest the cultural content of such festivals is limited and there is a fear that the more traditional culture of these societies is being replaced by a globalised, popular culture (Crespi- Vallbona\& Richards, 2007). This research aims to explore the role of arts festivals on local cultural consumptions, seeking in particular to gain a full understanding of attendees' consumptions on traditional versus globalised culture. This paper makes use of primary data obtained from attendees to the 2009 Hong Kong Arts Festival.

\section{Are Art Festivals Promoters of Local Culture?}

Art festivals are regarded as a time for celebration, marked by special observances, focusing on a cultural event consisting of a series of performances of works of fine arts (Quinn, 2005). A variety of benefits have been found to be gained from major international arts festivals. Of particular interest to this research is their benefit to the local cultural activity. McKercher, Ho\&Cros (2006) state that a key benefit of arts festivals is that they satisfy the sustainability criterion for tourism practices by providing opportunity to showcase the destination's ethnic background and cultural art heritage.

Therefore art festivals can be seen as integral to traditional cultural vibrancy. This is supported by Prentice and Andersen (2003, p. 8) in their statement of art festivals as a unique selling point of creativity as well as local heritage. Festivals are believed by some to be excellent examples of cultural tourism but in contradiction others 
believe them to be excellent examples of selling globalised culture. Crespi-Vallbona\& Richards (2007) point out that this divided view on festivals has been examined in a number of cases. However, it appears most of these evaluations have taken place within European events and few have looked to Asian examples. This study examines attendance to a number of events during the 2009 Hong Kong Arts Festival to help determine if art festivals play a role in promoting local culture consumption or encouraging international culture.

In theory, festivals should have the potential to attract both international and local attendees intending to experience various festival events. However, not all attendees can be assumed to be motivated to visit the destination to experience only a local or international form of art. As Prentice and Anderson (2003) state, there is a high risk in making such an assumption. They raise the fact that attendees may well experience other forms of local culture while attending the art festival. This assertion is particularly true as art festivals encourage a much broader spectrum of cultural consumptions. The research framework of this study captures the intentions of and the various activities undertaken by attendees to festival events aiming to underline other forms of cultural consumptions linked to the Hong Kong Arts Festival.

The Hong Kong Arts Festival (HKAF) is already perceived as a key festival destination event. According to (McCartney, 2010, p. 379) the HKAF has been a successful festival impacting considerably on the cultural life of Hong Kong. First staged in 1973 it is now considered a major international arts festival as well as the premier arts event in Hong Kong. A feature of its programming is to offer a balance of both international and local artists and companies in a variety of art forms including music, theatre, dance, popular entertainment, film and visual arts exhibitions. According to the HKAF, its "mission is to present an annual international festival of the highest standard for the enrichment of cultural life in Hong Kong. The Festival also serves as a catalyst to arouse wider public interest in the arts and to encourage artistic dialogue and cultural exchange" (http://www.hk.artsfestival.org/en/about). The Festival mounts over 100 performances in the space of 3 to 4 weeks and attracts in the vicinity of 100,000 ticket sales annually (McCartney, 2010, p. 376).

The question being asked here then is does the Festival further the concept of globalised culture through both the staging of international performances and attraction of international visitors or is it a catalyst for the development and sustainability of local culture?

\section{Method}

This study seeks to explore the impact of the 2009 Hong Kong Arts Festival on local cultural consumption. The study looks at preferences of two major segments, visitors and local residents to three core clusters of events (international performances, contemporary Chinese and traditional Chinese).This particular year was selected because the artistic programming displayed a balance of events under the core clusters being studied and in addition a wider international profile of attendees was recorded. The paper also explores further segmentation of international visitors and their consumption of other local cultural activities during the Festival. Primary data was obtained from over 1100 surveys of attendees to a variety of events during the 2009 Festival.

Data was collected during 41 different performances across the duration of the festival. Events were chosen to represent a broad range of performance types including different art forms, matinee and evening performances, and both weekday and weekend performances. Individual audience members were selected randomly to complete the survey. The survey was conducted in two versions, one for local residents and one for tourists attending the festival. Surveys were administered in both English and Chinese. Participants were asked to volunteer to complete a questionnaire during the performance and to return it in the same evening. A total of 1169 useable surveys were returned including both residents and visitors.

For analysis, the forty-one shows were categorised into three broad clusters based on their content (please refer to Appendix 1 for example performances). These were: Best International Performances, Traditional Chinese Performances and Contemporary Chinese Performances.

\section{Data Analysis}

\subsection{Descriptive Statistics}

In terms of the residency status, survey participants were overwhelmingly residents of Hong Kong rather than visitors from other countries. Approximately 89 per cent ( 88.9 per cent) of the survey participants indicated that they live permanently in Hong Kong. Only 11.1 per cent of participants were international visitor who were attending the Arts Festival (please refer to Table 1). 
Table 1. Demographics of respondents

\begin{tabular}{llcc}
\hline Category & & Residents & Visitors \\
\hline $\begin{array}{l}\text { Residency status as percentage } \\
\text { of total responses }\end{array}$ & 89 & 11 \\
Gender (\%) & Male & 36 & 44 \\
\multirow{5}{*}{ Age (\%) } & Female & 64 & 56 \\
& $<18$ & 22 & 3 \\
& $18-34$ & 36 & 36 \\
Education (\%) & Sch-54 & 29 & 32 \\
& S5+ & 13 & 30 \\
& Tertiary & 34 & 11 \\
& Higher Degree & 43 & 52 \\
\hline
\end{tabular}

Table 1 also shows the gender of those surveyed and it can be seen that the majority of respondentswere female (64 per cent for residents and 56 per cent for visitors). The majority of visitors were aged over 18 years with a reasonably even mix of respondents aged 18 to 34 years ( 36 per cent), 35 to 54 years ( 32 per cent) and over 55 years (30 per cent). Like visitors the largest age groups represented for residents were the 18 to 34 year group (36 per cent) and 35 to 54 year age group (29 per cent). However, the age profile for residents was different in that a significant number of respondents were under 18 years of age ( 22 per cent). The majority of visitors attending the festival had a post-secondary education at a diploma or higher level. In fact 43 per cent of respondents had at least a Bachelor degree with a further 36 per cent having a Masters degree or higher. The education profile of residents is slightly different possibly reflecting the higher proportion of children attending the performances. Two thirds of local respondents (66 per cent) indicated they had a post-secondary education at a diploma level or higher. Overall 36 per cent of respondents had at least a Bachelor degree with a further 23 per cent having a Masters degree or higher. About 30 per cent of residents indicated that the highest education level undertaken was secondary schooling.

Further analysis of the descriptive statistics show that overall it would appear that the data set is a reasonable distribution across gender, age and education which appears not to be skewed. Residency status is skewed towards local residents but this is to be expected given the audience base of the festival being predominantly local residents (see Table 2).

Table 2. Descriptive statistics

\begin{tabular}{|c|c|c|c|c|c|c|c|c|c|}
\hline & $\mathbf{N}$ & Min & Max & Mean & StdDev & Skewness & & Kurtosis & \\
\hline & Statistic & Statistic & Statistic & Statistic & Statistic & Statistic & $\begin{array}{l}\text { Std } \\
\text { Error }\end{array}$ & Statistic & $\begin{array}{l}\text { Std } \\
\text { Error }\end{array}$ \\
\hline Residency & 1163 & 1.00 & 2.00 & 1.1109 & 0.31417 & 2.481 & 0.072 & 4.163 & 0.143 \\
\hline Gender & 1159 & 1.00 & 2.00 & 1.6316 & 0.48258 & -0.546 & 0.072 & -1.705 & 0.144 \\
\hline Age & 1157 & 1.00 & 4.00 & 2.4045 & 0.9624 & 0.132 & 0.072 & -0.934 & 0.144 \\
\hline Education & 1134 & 1.00 & 5.00 & 2.6367 & 1.2415 & $-0,59$ & .073 & -1.123 & 0.145 \\
\hline
\end{tabular}

Residency: 1 = resident, 2 =visitor

Gender: 1 = male, 2 = female

Age: $1=$ under $18,2=18$ - 35 years, $3=35-54$ years, $4=$ over 55 years

Education: 1 = high school certificate, $2=$ diploma, $3=$ bachelor, $4=$ masters, $5=P h D$ 
Overall the demographics show that attendees to the Festival are more likely to be female, aged between 18 and 54 and have a tertiary education. This fits well with other studies of arts attendance patterns and would indicate a reasonable representation of arts audiences internationally (see for example Seaman, 2006). Of the demographic variables commonly used in studies of performing arts audiences, five have been identified repeatedly as important: education, age, income, occupation, and gender (Stafford \& Tripp, 2000, p. 32). Stafford and Tripp defined performing arts audiences as being middle-aged with higher education and more likely to be female (2000, p. 32). The statistics observed here are in line with this description, albeit slightly younger than middle aged.

In particular, in this study local resident statistics show a higher level of attendees aged less than 18 years along with a corresponding higher level of individuals with only a High School education. These statistics may indicate a significant level of local school students attending the Festival in addition to the more traditional arts attendee described above. If this is the case, it would appear that the Festival is successful in attracting both traditional arts attendees as well as young people to experience a variety of cultural activities associated with this event.

\subsection{Regression Analysis}

To explore further the types of events that attracted individuals to the Festival, respondents were asked to identify their main area of interest in attending the festival. Responses were grouped into 3 main clusters, namely to experience Traditional Chinese Performances, Contemporary ChinesePerformances orThe Best of International Performances. A series of multivariate regressions were undertaken to evaluatedifferent models of predicting festival attendance based on preference of event type.

\subsubsection{Regression Models for Predicting Show Attendances}

The first regression was conducted to measure the number of best international performances watched by the festival attendees. For this regression analysis, number of best international performances watched by the participants is considered as the dependent variable. Participants' country of origin (residency status), gender, age category, level of education, number of adults in the group, number of visits, and whether this was their first visit or not have been considered as independent variables. The final stepwise model (model 6) shows that the model is significant at $5 \%$ level (F-value $19.838, \mathrm{p}<0.000)$. Eleven percent $(11 \%)$ variation (R-square 0.110$)$ in the number of best international performance watched by the festival attendees is explained by the model (please refer to table 3). Festival attendees level of education, number of visits to the festival (previous years), gender, residency status, number of adults in the group, and whether this was the participant's first visit or not have come up as significant predictors of the number of international performances watched by the festival attendees.

Table 3. Model summary for regression 1

\begin{tabular}{|c|c|c|c|c|}
\hline Model & $\mathbf{R}$ & R Square & $\begin{array}{l}\text { Adjusted R } \\
\text { Square }\end{array}$ & Std. Error of the Estimate \\
\hline 1 & $.207^{\mathrm{a}}$ & .043 & .042 & 2.13171 \\
\hline 2 & $.271^{\mathrm{b}}$ & .073 & .072 & 2.09835 \\
\hline 3 & $.293^{\mathrm{c}}$ & .086 & .083 & 2.08505 \\
\hline 4 & $.313^{\mathrm{d}}$ & .098 & .094 & 2.07280 \\
\hline 5 & $.323^{\mathrm{e}}$ & .104 & .100 & 2.06644 \\
\hline 6 & $.332^{\mathrm{f}}$ & .110 & .104 & 2.06084 \\
\hline \multicolumn{5}{|c|}{ a. Predictors: (Constant), Education } \\
\hline \multicolumn{5}{|c|}{ b. Predictors: (Constant), Education, No_visit } \\
\hline \multicolumn{5}{|c|}{ c. Predictors: (Constant), Education, No_visit, Gender } \\
\hline \multicolumn{5}{|c|}{ d. Predictors: (Constant), Education, No_visit, Gender, visit_l } \\
\hline \multicolumn{5}{|c|}{ e. Predictors: (Constant), Education, No_visit, Gender, visit_1, Residency } \\
\hline
\end{tabular}


Positive coefficient values for level of education, number of festival visits, and whether this was their first visit (Please refer to Appendix 2a) indicate that festival attendees with higher educational qualifications are more likely to attend international performances than the attendees with low educational qualifications. Attendees who have the highest number of visits to the festival watched the most international performances. This is supported by the finding that those who attended the festival for the first time watched less international performances than people who attended the festival multiple times. It was also found that local residents watched more international performances than the international visitors. Negative coefficient for gender shows that female attendees watched less international shows than the male attendees. Number of adults in the group also has a negative impact on the number of international performances watched.

The regression equation used to measure the number of best international performances watched can be denoted as:

No. of best international performance performances $=1.728+0.190$ (Education) +0.148 (No. of Visit) 0.121 (Gender) +0.103 (Visit_1) - 0.080 (Residency) -0.079 (No. of adults in group)

The second regression was conducted to build a model for measuring number of traditional Chinese shows watched by the festival attendees. For this model, number of traditional Chinese performances watched by the festival attendees was considered as the dependent variable. Participants' country of origin (residency status), gender, age category, level of education, number of adults in the group, number of visits (previous years) and whether this is their first visit or not have been considered as independent variables.

A total of four models were created. The fourth and final model is significant at $5 \%$ level of significance (F-value $18.107, \mathrm{p}<0.000$ ). R-square value 0.07 indicates that only $7 \%$ variation in the number of traditional Chinese performances watched by the festival attendees can be explained by the model. Festival attendees' age, number of festival visits, and residency status were all significant predictors of the number of traditional Chinese performances watched by the attendees (please refer to table 2b). Positive coefficient for age indicates that older festival attendees watched more traditional Chinese performances than the younger attendees. The number of previous festival visits was found to be negatively related to the number of traditional Chinese shows seen, meaning the people who had visited the festival fewer times tended to see more traditional Chinese shows. The regression model to measure the number of traditional Chinese performances watched can be presented as:

No. of traditional Chinese performances $=0.267+0.243$ (Age) -0.105 (No. of Visit) -0.076 (Residency) + 0.074 (Transport Cost)

Table 4. Model summary for regression 2

\begin{tabular}{lllll}
\hline Model & R & R Square & Adjusted R Square & $\begin{array}{l}\text { Std. Error of the } \\
\text { Estimate }\end{array}$ \\
\hline $\mathbf{1}$ & $.222^{\mathrm{a}}$ & .049 & .048 & .71763 \\
$\mathbf{2}$ & $.246^{\mathrm{b}}$ & .060 & .058 & .71373 \\
$\mathbf{3}$ & $.254^{\mathrm{c}}$ & .065 & .062 & .71254 \\
$\mathbf{4}$ & $.264^{\mathrm{d}}$ & .070 & .066 & .71089 \\
\hline a. Predictors: (Constant), Age & & \\
b. Predictors: (Constant), Age, No_visit \\
c. Predictors: (Constant), Age, No_visit, Residency \\
d. Predictors: (Constant), Age, No_visit, Residency, Transport
\end{tabular}

The third and final regression analysis was conducted to build a model to measure the number of contemporary Chinese performances watched by the festival attendees. For this model, the number of contemporary Chinese shows watched has been considered as the dependent variable. Participants' country of origin (residency status), gender, age category, level of education, number of adults in the group, number of visits, and whether this is their first visit or not were considered as independent variables.

The final model shows that the model is significant at $5 \%$ level of significance (F- value 6.701, $\mathrm{p}<0.001$ ). Although the model is significant at $5 \%$ level of significance, it can't be considered as a good model because 
only a fraction (1.4\%) of the variation in the dependent variable is explained by the model. Poor R-square value indicates that the model is not a good fit for the data.

Festival attendees' age and residency status were found to be significant predicators of the number of contemporary Chinese performances watched by the festival attendees. Like the second regression, attendees' age is positively related to number of contemporary Chinese shows watched, which indicates that older festival attendees watched more contemporary Chinese shows than younger attendees (please refer to appendix $2 \mathrm{c}$ ). The regression model to measure the number of contemporary Chinese performances watched can be denoted as:

$$
\text { No. of performances }=0.843+0.910(\text { Age })+0.085 \text { (Residency) }
$$

Table 5. Model summary for regression 3

\begin{tabular}{lcccc}
\hline Model & R & R Square & Adjusted R Square & Std. Error of the Estimate \\
\hline $\mathbf{1}$ & $.081^{\mathrm{a}}$ & .007 & .006 & 1.01033 \\
$\mathbf{2}$ & $.117^{\mathrm{b}}$ & .014 & .012 & 1.00722 \\
\hline
\end{tabular}

a. Predictors: (Constant), Age

b. Predictors: (Constant), Age, Residency

\section{Discussion}

It can be seen from the above analyses that the Festival plays an important dual role within the cultural context of Hong Kong. On the one hand, the majority of the audience is made up of local residents so it must fulfil the needs of this constituency. However, there is also a significant proportionof visitors to Hong Kong that also attend the Festival (around 10 per cent of respondents) which demonstrates the global focus expected of a major international arts festival.

There is no doubt that the festival attracts a traditional arts audience to many of its performances however there is a significant component of the local resident population, in particular school students and those under 18 year of age. This demonstrates the ability of the Festival to attract and potentially develop new audiences to cultural performances across a variety of genres, which is an important component of cultural development. Local residents were also asked about their frequency of attendance to past festivals and 20 per cent of respondents indicated that this was the first time they had attended a Hong Kong Arts Festival event. Again this figure supports the notion that the festival is creating new consumers of cultural products.

Figure 2 (Appendix 3)displays the statistics for each of the three programmatic clusters of interest aggregated by age. As notedabove, aparticipants' age was a significant factor in determining attendance desires. It can be seen below that around 50 per cent of all age groups consistently saw the best of international performances being a key reason for attending the festival. Around 20 per cent of those under 54 wished to attend based on contemporary Asian performances, dropping to 15 per cent for those over 55. Finally, the younger a person's age the less likely they were to see performances based on traditional Asian work, with the highest level of attraction being those over 55 years of age ( 26 per cent).

This notion of a dominance of international work is supported when looking at the clusters in regard to residency status as just over half of local residents attending (51 per cent) were inspired to attend the Festival to see these international performances. This would appear to be in line with a key component of a major arts festival's mission, to bring the best the world has to offer to the residents of the city or state. This would also seem to concur with the thesis that festivals contribute to a notion of globalising culture. However this global culture is not seen as a totally dominant factor as the remaining half of respondents indicated that they were alsointerested in local Chinese culture, both traditional and contemporary. This was particularly true for international visitors and residents aged over 55 years. This would indicate that the Festival is not necessarily stifling the local cultural scene but in fact it could be argued that it is supporting this in a significant way through showcasing local Asian performing arts companies alongside major international companies.

Interestingly when looking at programming of the three clusters in the Festival, 60 per cent of performance events where classified as international companies and artists. The remaining 40 per cent were Chinese companies and artists with about 28 per cent being contemporary and 12 per cent traditional performances. This demonstrates a slight bias toward international artists which would appear to be in line with the desires of local residents who are interested in seeing these types of performances. However the strong presence of Chinese 
artists and companies on the Festival program indicates the level of support given by the Festival to local cultural production.

When looking at international visitors to Hong Kong the attendance patterns also support the notion that local culture in a variety of forms is being strengthened through the activities of the Festival. For example, visitors were more likely to attend performances by both traditional and contemporary Chinese companies and artists than local residents. This indicates that there is keen interest from visitors to experience local culture in a festival setting.

In addition, while in Hong Kong many visitors also took advantage of other cultural activities outside the Festival (seeFigure 3, Appendix 3). Over two thirds of all international visitors also attended local museums and almost half of respondents visited local heritage sites, demonstrating a wider cultural impact. Of those surveyed the majority of visitors were from other Asian countries and Europe. These two geographic areas accounted for over 75 per cent of respondents ( 37 per cent and 39 per cent respectively). Around 65 per cent of Asian visitors and 75 per cent of European visitors also visited or intended to visit a museum while in Hong Kong. This was the largest single additional activity listed by these visitors. Interestingly 67 per cent of European visitors also intended to visit heritage sites, however only 37 per cent of those from Asian countries intended to do so.

However whether this interaction with other cultural activities can be attributed in any way to the Festival would rely on some indication of why visitors had come to Hong Kong in the first place. Of those audience members who were identified as visiting Hong Kong approximately one third (33per cent) came to Hong Kong specifically to attend the Festival.Of those visitors surveyed that indicated they did not come to Hong Kong specifically to attend the Festival, a further 30 per cent stated that they did change their travel plans to accommodate the festival.

Therefore almost half of visitors surveyed indicated that they either came to Hong Kong because of the Festival or changed their trip to accommodate attending the Festival. This indicates that the festival is an important driver in developing visitor interest in local culture on a number of levels. Through activities directly related to the Festival and by visiting other cultural venues and sites, tourists are experiencing a wide variety of cultural activities from artistic performances, to museums and heritage event to Hong Kong shopping and cuisine.

\section{Conclusion}

The analysis of the Hong Kong Arts Festival shows that there were significant differences between attendance patterns of local residents and visitors. Local residents were attracted more to international performances while visitors were attracted to Chinese performances (both contemporary and traditional). Findings also indicated that there is an indirect positive effect of the Festival on local cultural activities occurring during the event but not specific to it.

This result highlights that arts festivals fulfil a dual role of bringing the best of international art to local residents while also showcasing the traditional and contemporary culture of a region. Findings from the Hong Kong Arts Festival indicate thatthe consumption of culture is derived from two influential factors. The first is the core cluster of international culture performances which indicates that Hong Kong serves as a catalyst for globalised culture.

Secondly, the findings also point to a demand for a balance of events in the festival setting through the other two clusters of traditional and contemporary interpretations of local culture. In particular, international visitors to Hong Kong cited attending Chinese performances as a key driver in their decision to attend the festival.

This result shows that there is a balance between demand for consumption of both globalised culture and local culture. This provides a unique opportunity for cultural policy makers to explore how international festivals can use the promotion of a globalised culture to create a space for the introduction of a more contemporary interpretation of local culture. The challenge, however, for policy makers is to provide the structure for festivals such as this to take on and maintain the key role in cultural development as well as preserve the real meaning of festivals; a place of rich, social and local cultural reproduction.

\section{Opportunity for Future Study}

The need to identify and evaluate the most effective structures for arts and cultural festivals of this scale remains a seminal area of study for the cultural sector. It is the view of the authors that further studies can enlighten how the correct balance of design in regard to choices of artistic and cultural content can be achieved. To do this however it is important to identify the main purpose or agenda of the particular festival or host community. This can of course vary depending on the weight given to various factors. At one end there is the maintenance and presentation of local heritage and culture to both educate local communities as well as international visitors 
about the culture of the place. At the other end of the spectrum there is the desire to bring international cultural activity to the local communities which may also attract international interest through visitation to particular performances. Either way there is also the intention to attract international visitors and therefore be a catalyst for local tourism. This perhaps is an area for further study which requires the testing of different structures to evaluate the effectiveness of this attraction. Indeed it may well be possible to be effective from both perspectives within the one festival as findings from the 2009 Hong Kong festival indicate.

\section{References}

Arcodia, C., \& Whitford, M. (2006). Festival Attendance and the Development of Social Capital. Journal of Convention and Event Tourism, 8(2), 1-18.

Crespi-Vallbona, M., \& Richards, G. (2007). The Meaning of Cultural Festivals: Stakeholder Perspectives in Catalunya. International Journal of Cultural Policy, 13(1), 103-120.

Crompton, J.L., \& McKay, S.L. (1997). Motives of visitors attending festival events. Annals of Tourism Research, 24(2), 425-439.

Debord, G. (1992). Society of the spectacle and other films. London: Rebel Press.

Falassi, A. (1987). Festival: definition and morphology. In A. Falassi (Ed), Time out of time: essays on the festival(pp. 1-10). Albuquerque, NM: University of New Mexico Press.

Fjell, L. (2007). Contemporary Festival: Polyphony of Voices and Some New Agents. Stud. Ethnol. Croat, 19, 129-149.

Hong Kong Arts Festival. (2009). In the Hong Kong Arts Festival. Retrieved March 7, 2009 from http://www.hk.artsfestival.org/en/about/

MacAloon J.J. (1984). Olympic Games and the theory of spectacle in modern societies. In J. MacAloon (Ed). Rite, drama, festival, spectacle (pp. 241-281). Philadelphia, PA: Institute for the Study of Human Issues.

McCartney, G. (2010). Event Management: An Asian Perspective. Singapore: McGraw Hill.

McKercher, B., Ho, P.S.Y., \& Cros, H. (2004). Attributes of popular culture attractions in Hong Kong. Annals of Tourism Research, 31, 393-407.

Prentice, R., \& Andersen, V. (2003). Festival as Creative Destination. Annals of Tourism Research, 30(1), 7-30.

Quinn, B. (2005). Arts Festivals and the City. Dublin Institute of Technology, 42(5/6), 927-943. http://dx.doi.org/10.1080/00420980500107250

Richards, G., \& Wilson, J. (2005). Developing creativity in tourist experiences: A solution to the serial reproduction of culture? Tourism Management, 27, 1209-1223.

Seaman, B. (2006). Empirical Studies of Demand for the Performing Arts. In V. Ginsburgh, D. Throsby (Ed), Handbook of the Economics of Art and Culture (pp. 415-472). North- Holland.

Stafford, M.R., \& Tripp, C. (2000). Age, Income, and Gender: Demographic Determinants of Community Theater Patronage. Journal of Nonprofit \& Public Sector Marketing, 8(2), 29-43. 


\section{Appendix 1}

Table 6. Classification of performances (examples)

\begin{tabular}{ll}
\hline \multicolumn{1}{c}{ Classification } & \multicolumn{1}{c}{ Name of performance } \\
\hline \multirow{2}{*}{ Traditional Chinese } & National Ballet of China: The Peony Pavilion \\
& Shanghai Peking Opera Troupe \\
& Shanghai Yueji Opera Theatre \\
& Black Swan \\
& ExxonMobil Vision: Primary Shapes - an Eternal Golden Braid \\
Contemporary & Murder in San Jose \\
Chinese & Paper Tiger Theatre Studio: Cool \\
& Asia Pacific Dance Forum \\
Best International & Bernard Haitink and the Chicago Symphony Orchestra \\
& Chick Corea and John McLaughlin 5 Piece Band \\
& CircoAreo: Un cirque plus juste \\
\hline
\end{tabular}

\section{Appendix 2a}

Table 7. Coefficients for regression 1

\begin{tabular}{|c|c|c|c|c|c|}
\hline \multirow[b]{2}{*}{ Model } & & \multicolumn{2}{|c|}{ Unstandardized Coefficients } & \multicolumn{2}{|c|}{$\begin{array}{l}\text { Standardized } \\
\text { Coefficients }\end{array}$} \\
\hline & & $\mathrm{B}$ & Std. Error & Beta & $\mathrm{t}$ \\
\hline \multirow[t]{2}{*}{1} & (Constant) & 1.089 & .160 & & 6.808 \\
\hline & Education & .362 & .055 & .207 & 6.578 \\
\hline \multirow[t]{3}{*}{2} & (Constant) & .937 & .160 & & 5.868 \\
\hline & Education & .312 & .055 & .178 & 5.676 \\
\hline & No_visit & .064 & .011 & .178 & 5.659 \\
\hline \multirow[t]{4}{*}{3} & (Constant) & 1.837 & .293 & & 6.276 \\
\hline & Education & .287 & .055 & .164 & 5.207 \\
\hline & No_visit & .062 & .011 & .172 & 5.518 \\
\hline & Gender & -.509 & .139 & -.114 & -3.658 \\
\hline \multirow[t]{5}{*}{4} & (Constant) & .871 & .399 & & 2.181 \\
\hline & Education & .274 & .055 & .156 & 4.990 \\
\hline & No_visit & .052 & .012 & .145 & 4.548 \\
\hline & Gender & -.532 & .139 & -.119 & -3.836 \\
\hline & visit_1 & .597 & .169 & .112 & 3.528 \\
\hline \multirow[t]{6}{*}{5} & (Constant) & 1.646 & .495 & & 3.326 \\
\hline & Education & .292 & .055 & .167 & 5.299 \\
\hline & No_visit & .053 & .012 & .147 & 4.614 \\
\hline & Gender & -.548 & .138 & -.122 & -3.960 \\
\hline & visit_1 & .558 & .169 & .105 & 3.299 \\
\hline & Residency & -.681 & .258 & -.081 & -2.637 \\
\hline \multirow[t]{7}{*}{6} & (Constant) & 1.728 & .495 & & 3.493 \\
\hline & Education & .333 & .057 & .190 & 5.803 \\
\hline & No_visit & .053 & .011 & .148 & 4.649 \\
\hline & Gender & -.542 & .138 & -.121 & -3.931 \\
\hline & visit_1 & .552 & .169 & .103 & 3.267 \\
\hline & Residency & -.670 & .257 & -.080 & -2.603 \\
\hline & No_adults & -.137 & .055 & -.079 & -2.498 \\
\hline
\end{tabular}




\section{Appendix 2b}

Table 8. Coefficients for regression 2

\begin{tabular}{|c|c|c|c|c|c|c|}
\hline \multirow[b]{2}{*}{ Model } & & \multicolumn{2}{|c|}{ Unstandardized Coefficients } & \multicolumn{3}{|c|}{$\begin{array}{l}\text { Standardized } \\
\text { Coefficients }\end{array}$} \\
\hline & & B & Std. Error & Beta & $\mathrm{t}$ & Sig. \\
\hline \multirow[t]{2}{*}{1} & (Constant) & .029 & .062 & & .468 & .640 \\
\hline & Age & .171 & .024 & .222 & 7.072 & .000 \\
\hline \multirow[t]{3}{*}{2} & (Constant) & .052 & .062 & & .842 & .400 \\
\hline & Age & .185 & .024 & .241 & 7.605 & .000 \\
\hline & No_visit & -.013 & .004 & -.108 & -3.407 & .001 \\
\hline \multirow[t]{4}{*}{3} & (Constant) & .233 & .107 & & 2.169 & .030 \\
\hline & Age & .191 & .025 & .249 & 7.809 & .000 \\
\hline & No_visit & -.013 & .004 & -.108 & -3.411 & .001 \\
\hline & Residency & -.182 & .088 & -.065 & -2.058 & .040 \\
\hline \multirow[t]{5}{*}{4} & (Constant) & .267 & .108 & & 2.467 & .014 \\
\hline & Age & .187 & .025 & .243 & 7.617 & .000 \\
\hline & No_visit & -.013 & .004 & -.105 & -3.339 & .001 \\
\hline & Residency & -.216 & .089 & -.076 & -2.413 & .016 \\
\hline & Transport & .000 & .000 & .074 & 2.346 & .019 \\
\hline
\end{tabular}

\section{Appendix 2c}

Table 9. Coefficients for regression 3

\begin{tabular}{|c|c|c|c|c|c|c|}
\hline \multirow[b]{2}{*}{ Model } & & \multicolumn{2}{|c|}{ Unstandardized Coefficients } & \multicolumn{2}{|l|}{$\begin{array}{l}\text { Standardized } \\
\text { Coefficients }\end{array}$} & \multirow[b]{2}{*}{ Sig. } \\
\hline & & $\mathrm{B}$ & Std. Error & Beta & $\mathrm{t}$ & \\
\hline \multirow[t]{2}{*}{1} & (Constant) & .514 & .087 & & 5.914 & .000 \\
\hline & Age & .086 & .034 & .081 & 2.522 & .012 \\
\hline \multirow[t]{3}{*}{2} & (Constant) & .843 & .152 & & 5.562 & .000 \\
\hline & Age & .097 & .034 & .091 & 2.833 & .005 \\
\hline & Residency & -.331 & .125 & -.085 & -2.646 & .008 \\
\hline a. Depe & ndent Variab & : Cont Chinese & & & & \\
\hline
\end{tabular}




\section{Appendix 3}

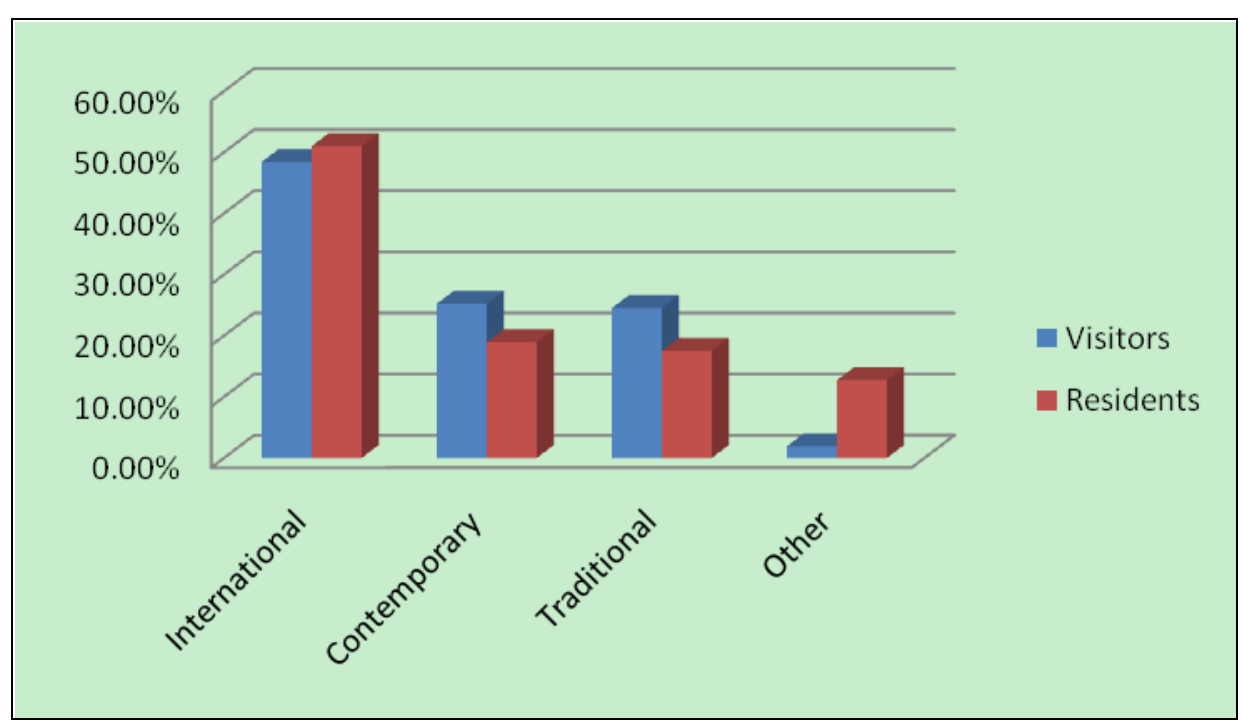

Figure 1. Main interest in attending the festival

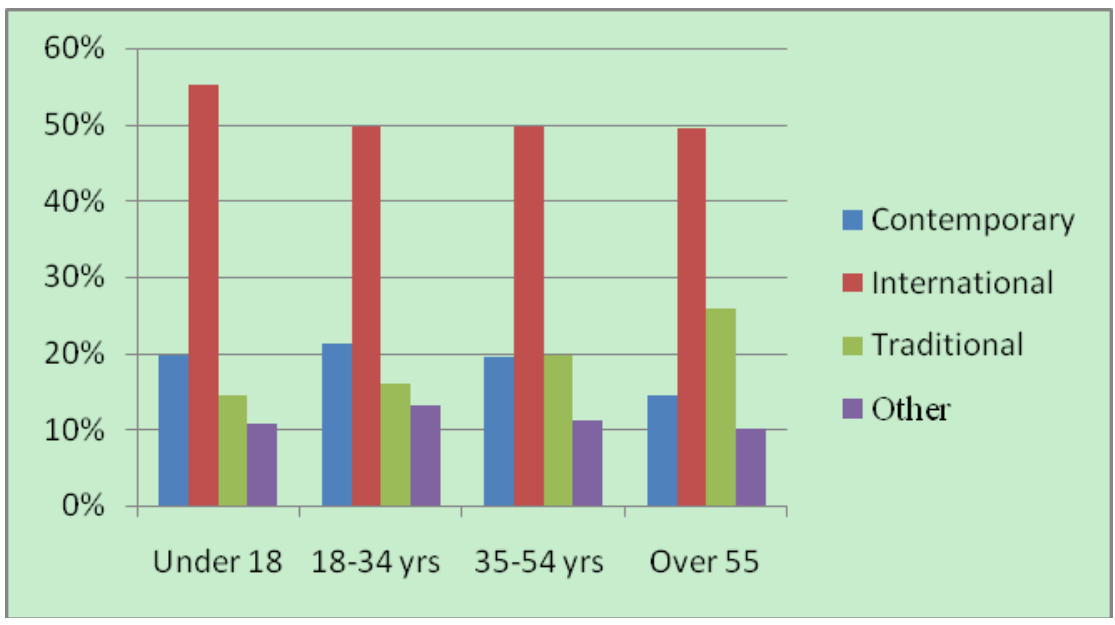

Figure 2. Interest in attending festival based on age

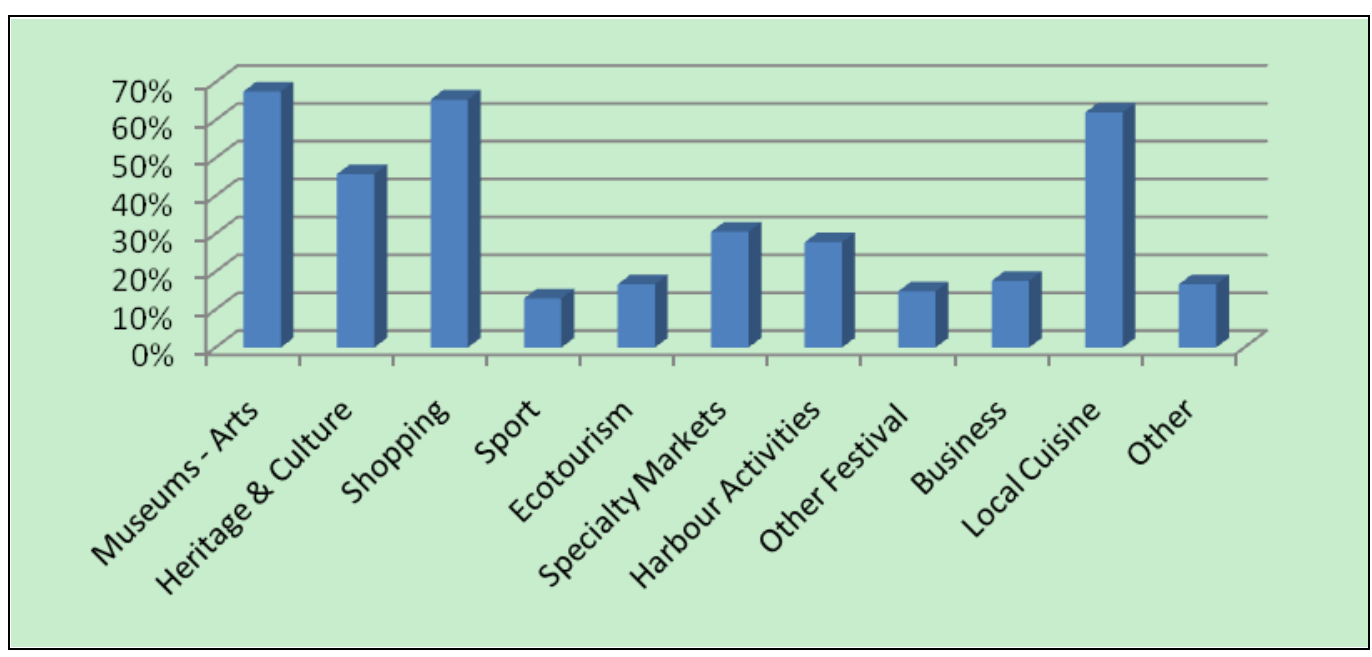

Figure 3. Other activities undertaken by visitors during the festival 